\title{
Post-Truth Siyaset Bağlamında Yeni Medya: 2019 Yerel Seçimi Örneğinde Bir İnceleme
}

\author{
Ayșe Fulya ȘEN ${ }^{12}$ \\ Hacer TAȘDELEN ${ }^{3}$
}

\begin{abstract}
Öz
Bu çalışma, gerçeğin değersizleşmesi anlamına gelen post-truth kavramına ve yeni medya üzerinden yayılan yalan içeriklere odaklanmaktadır. Bu çalışmada, 31 Mart 2019 yerel seçimi döneminde yeni medya üzerinden yayılan yalan içerikler irdelenmiştir. Bu çalışmanın amacı, haber sitelerinde ve sosyal ağlarda 31 Mart 2019 yerel seçimi sürecinde yayılan yalan içeriklerin yoğunluğunu, içeriklerin hangi mecralarda, ne şekillerde üretildiğini ve üretilen içeriklerin temalarını ortaya koymaktır. İki aşamadan oluşan çalışmada, ilk olarak Teyit.org tarafından 31 Mart 2019 yerel seçim döneminde tespit edilen yalan içeriklere yönelik betimsel içerik analizi yapılmış, ikinci aşamasında ise yalan içeriklerin temaları incelenmiş ve yeni medyanın yalan içeriklerin yayılmasında belirleyici bir rol oynadığı sonucuna ulaşıımışır.
\end{abstract}

Anahtar Kelimeler: Post-truth, yalan haber, dijital algoritma, yeni medya, siyasal iletişim, 2019 yerel seçimi

Atıf: Șen, A. F. ve Tașdelen, H. (2020). Post-Truth Siyaset Bağlamında Yeni Medya: 2019 Yerel Seçimi Örneğinde Bir İnceleme. Akdeniz Üniversitesi İletișim Fakültesi Dergisi, 33, s. 11-34

1 Sorumlu yazar (Corresponding author)

2 Prof. Dr., Fırat Üniversitesi İletişim Fakültesi, fulyasen@firat.edu.tr, ORCID Numarası: 0000-0003-3350-8292.

3 Doktora öğrencisi, Fırat Üniversitesi Sosyal Bilimler Enstitüsü Iletişim Bilimleri Ana Bilim Dalı, hacertasdelen@gmail.com, Orcid ID: 0000-0002-8122-0560. 


\title{
New Media in the Context of Post-Truth Politics: A Study on the Example of the 2019 Local Election
}

\begin{abstract}
This study focuses on the concept of post-truth meaning the devaluation of the truth, and the fake news spread by the new media. In this study, the contents of fake news spread by new media during the 31st March 2019 local election were examined. The aim of the study is to reveal the density of fake news spread on news sites and social networks during the local election process Also the study deals with questions like in which channels and in what ways the content is produced and what are the themes of the produced content. The study, consisting of two stages, a descriptive content analysis was first conducted for fake news identified by Teyit.org during the local election period of 31 st March 2019. In the second stage, the themes of the fake news were examined, and it was concluded that the new media played a determining role in the spread of fake news.
\end{abstract}

Keywords: Post-truth, fake news, digital algorithm, new media, political communication, 2019 local elections

\section{Giriș}

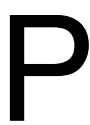
ost-truth kavramı başlangıçta Amerika'da post-truth siyaset veya post-truth toplum biçiminde popüler siyasetin bir kavramı olarak ortaya çıkmış ve sonrasında pek çok dilde hızı ıir şekilde yaygınlık göstermiştir (Harsin, 2018). Son zamanlarda en çok duyulan ve tartışılan kavramlardan biri olan post-truth, Türkçe'ye 'hakikat sonrası', 'gerçek-ötesi' veya 'gerçek-sonrası' şeklinde tercüme edilmiştir. Bu kavramın ortaya çıkmasında Amerika'daki 2016 seçimleri ve Trump'ın seçim zaferi bir dönüm noktası olarak kabul edilmektedir. Oxford İngilizce Sözlüğü, post-truth kavramını 2016 yılının sözcüğü olarak seçmiş ve "kamuoyunu biçimlendirmede objektif gerçeklerin daha az etkili olduğu durumlar" olarak tanımlamıştır. Post-truth (hakikat sonrası) periyodik bir terim olmaktan çıkmış, siyasi yorumlarda bir dayanak noktası haline gelmiş ve büyük medya kuruluşları tarafından sıklıkla kullanıımaya başlanmıştır. Özellikle, 2016'daki Brexit referandumu ve Amerikan başkanlık seçimleri bağlamında bu kullanım sıklığı artmış ve çoğunlukla post-truth siyaset kavramıyla ilişkilendirilmiştir (OED, 2016). Keyes'e göre, yalanların kirli ve beyaz şeklinde ayrıldığı bir dönemden, yalanın silikleştiği ve gerçekle ayırt edilemez olduğu bir döneme geçiş yapılmıştır. Bu dönem 'hakikat sonrası bir çağ' olarak adlandırılmaktadır. Bu çağda, yalanlar tereddüt edilmeden, suçluluk duyulmadan, hiçbir şekilde utanma hissetmeden söylenmektedir. Hakikat sonrasının zeki insanları, yalan söylemekten suçluluk duymak yerine, suçluluk duygusundan kurtulmak için gerçekleri örtbas etmeyi seçmektedirler (2017: 22).

Birleşik Krallık'ın Avrupa Birliği'nden çıkmasına dair referandum sürecinde, yani Brexit tartışmaları sırasında, Brexit savunucularının birçok argümanı yetkin ağızlardan 
dolaşıma sokmaları ve bu yalan iddiaların kitlelerce doğru kabul edilip seçim sonuçlarını etkilemesi $A B$ üyeliğini savunanların aleyhine sonuçlar doğurmuştur. Bu asılsız iddialar arasında İngiliz Sağlık Sistemine (NHS) gidecek paraların, AB'ye destek olarak aktarıldığı, yani sağlık sisteminden yeterince faydalanamayan İngilizlerin AB'yi suçlaması gerektiği yer almaktadır. Her ne kadar bu iddianın gerçeği yansıtmadığı yetkili ağızlar tarafından kanıtlarla reddedilmiş olsa da seçimin sonucunda $A B$ üyeliğini savunanları üzecek karar çıkmıştır (Gross, 2017: 1).

Bir sonraki kırılma noktası da seçim sürecinde birçok yalan içeriğin dolaşıma sokulduğu Amerika başkanlık seçimleri olmuştur. Bağımsız bir araştırma ve denetleme kuruluşu olan PolitiFact, tarafından yapılan analizler, durumun vahametini gözler önüne sermiştir. PolitiFact, Amerika başkanlık seçimi sürecinde Donald Trump'ın yaptığı açıklamaların \%69' unu yanlış veya çoğunlukla yanlış olarak değerlendirmiştir. Rakibi Hillary Clinton için ise bu oran \%26 olmuştur. Yine bu süreçte, sosyal medyada özellikle Twitter'da Trump lehine yapılan manipülatif içerikler incelendiğinde çoğunluğun 'tweetbot' olarak tabir edilen sanal hesaplar tarafından yapıldığı görülmüştür. Sosyal medyadaki Trump yanlısı internet akışının, Hilary Clinton'a oranla dört kat daha fazla olduğu da yine bu araştırmanın sonuçlarından biridir (Kollanyi vd., 2016: 1-5). Donald Trump'ın seçim sürecinde yaptığı manipülatif açıklamalar ve ırkçı söylemler ciddi oranda eleştiriler getirmiş olsa da seçimin kazananı Trump olmuştur. Amerikan seçimlerindeki Trump zaferinden sonra, gerçek dışı içeriklerin çok kullanılması ve gerçek dışı üretilen içeriklerin doğrulanmasına rağmen sonucun değişmemesi Trump'ın seçilmesinde post-truth kavramının rolünü göstermektedir (Kellner, 2018: 89). Trump'un manipülatif içeriklerinin seçim üzerinde etkili olduğunu düşünenlerin aksine Swire vd. (2017: 354) yaptıkları araştırmada, Trump'ın sahte iddialarının destekçileri için önemli olmadığını, en azından duygularını veya oy verme niyetlerini değiştirecek düzeyde olmadığını ortaya koymuştur.

Post-truth veya hakikat sonrası siyaset ise, bir şeyin en iyi ve en kötü temsiline dayanan bir siyaset tarzı olarak tanımlanmaktadır (Bilgin, 2017). Post-truth kavramı toplumun genelinde rutin hale gelen bariz yalanlara gönderme yapmakta ve siyasetçilerin bir eleştiri olmaksızın yalan söyleyebilecekleri anlamına gelmektedir. Buradaki ironi post-truth eğilimlerden yararlanan siyasetçilerin de pek çok insanın kendilerine inanmak konusunda iyi niyetli olduğu gerçeğine bağlı olmaşıdır (Higgins, 2016: 9). Posttruth bir alan olmakla eleştirilen günümüz Amerikan siyasetinde -demokratik bir seçim yarışında oyunun kuralı gereği- siyasetçilerin eylemleri nedeniyle sorumluluktan kaçmak ve gerekçeler sunmak için gerçeği eğip bükmeleri sıkça karşılaşılan bir durumdur. Gerçeklik olarak bilinen, aslında "uygulamaların, söylemlerin, siyasetin ve kurumların konfigürasyonundan kaynaklanan” bu modern olgunun giderek bozulmaya başladığı görülmektedir. Özellikle, gerçek ve gerçek olmayanı ayırmayı zorlaştıran 'fake news (yalan haber)' olgusu da post-truth döneme girildiğini göstermektedir. Diğer taraftan, Twitter ve diğer sosyal medya platformları da modern gerçeğin dağılmasının bir parçasını oluşturmaktadır (Sismondo, 2017).

Post-truth olgusu, sahte veya yanlış haberler, söylentiler, aldatmacalar ve siyasal yalanlar gibi iletişim formlarıyla ilişkilendirilmektedir. Ayrıca, kutuplaşma, etik dışı politikacılar ve sosyal medya da post-truth ortamı beslemektedir. Post-truth yurttaşların ve 
politikacıların artık gerçeğe saygı duymadıkları değil, aynı zamanda inandıkları veya hissettikleri şeyi doğru olarak kabul ettikleri toplumsal ve politik bir durum olarak kabul edilmekte ve haber medyasını kapsayan bir "toplumsal güven dağılımı" olarak tanımlanmaktadır. Post-truth, söylentiler, komplolar, aldatmacalar, yalan haberler, gerçeği kontrol etme ve filtre balonları gibi popüler formları ve aynı zamanda çok sayıda etkisi ile tarihsel bağlamı içinde anlaşılacak bir olgudur (Harsin, 2018).

Post-truth üzerine yapılan iletişim araştırmaları çoğunlukla nicel metodolojik yaklaşımlara dayanmaktadır. Çalışmalar önemli ampirik veriler sağlarken, derin bir kuramsal tartışma içermemektedir. Örneğin, Kavanagh ve Rich (2018), "Gerçeğin Çürümesi (Truth Decay)" başlıklı çalışmalarında son yirmi yıl boyunca, Amerika Birleşik Devletleri'ndeki ulusal politik ve sivil söylemi "gerçeğin çürümesi» olarak nitelendirmişler, bu durumu gerçek ile görüş arasındaki çizginin bulanıklaşması, gerçeklerle olguların ve verilerin analitik yorumlanmasıyla ilgili bir anlaşmazlık olarak anlamlandırmışlardır. Yazarlar, bu eğilimleri meydana getiren dört unsura işaret etmişlerdir. Bu unsurlar; bilişsel önyargı, sosyal medya ve haber döngüsü başta olmak üzere bilgi sisteminde meydana gelen değişiklikler, eleştirel düşünceye dayanan medya okuryazarlığının gelişmemesi ve hem siyasal hem de demografik kutuplaşmadır. Kavanagh ve Rich, bu unsurların hakikat bozulmasına yol açan sivil söylemlerin aşınması, siyasetin felç olması, bireylerin siyasal ve sivil kurumlardan kopması ve ulusal politika konusunda bir belirsizliğin ortaya çıkması gibi sonuçlar doğurduğunu belirtmektedir.

2000'li yılların başında, çevrimiçi haberlerin gelişmesi -bakış açısı çeşitliliğini artırmakla birlikte- benzer düşünen bireyleri karşıt perspektiflerden yalıtan 'yankı odaları' veya 'filtre baloncukları' gibi yeni bir sorunu gündeme getirmiştir. Önceki medya teknolojilerinden çok farklı bir yapıya sahip olan Facebook'ta içerikler bilgi denetimi veya içerik muhakemesi olmaksızın kullanıcılar arasında aktarılabilmekte ve çok geniş bir kitleye ulaşabilmektedir. Özellikle, ABD'deki 2016 seçimlerinden sonra, sosyal medyada dolaşıma giren "yalan haberler" bir endişe konusu olmuştur. ABD'li yetişkinlerin \%62'sinin haberleri sosyal medyadan alması ve en popüler yalan haber hikayelerinin Facebook'ta en popüler ana akım haber hikayelerinden daha yaygın olarak paylaşılması bu endişenin en önemli kanıtları olarak gösterilmiştir (Allcott ve Gentzkow, 2017: 211212). Facebook, yalan haberler söz konusu olduğunda en çok dikkat çeken çevrimiçi forumdur ve özellikle yüksek nitelikli müzakereleri teşvik etmekten uzak görünmektedir. Örneğin, Facebook’taki tartışmalar, gerçek zamanlı olarak gerçekleşmekte, bu da gelişmiş argümanlar yerine kişisel saldırıları ve kısa mesajları teşvik etmektedir. Facebook'un kişinin kendisiyle benzer inançlara sahip kişilerle iletişim kurmasını sağlaması özelliği, internet algoritmalarının kişiyi geçmiş internet etkinliğine dayalı içeriklerle beslemesi (filtre balonları) ile güçlendirilmektedir. Buna göre, çevrimiçi alanların, yalan haberlerin endemik bir sorun gibi göründüğü müzakere ve 'gerçeği izleme' için elverişli olmadığını ileri sürmek mümkündür (Wikforss, 2020).

Medya teknolojilerinin siyaset alanını değiştirmesinin ve sosyal medyanın yalan haberlerin yayılması için çok uygun bir zemin yaratması ve bir siyasal bilgi kaynağı olmasının sonucu olarak post-truth ve yalan haber olgusu tartışılmaya başlanmıştır. AlIcott ve Gentzkow (2017), bu tartışmayı çerçevelemek için teorik ve ampirik bir arka plan sundukları çalışmalarında ABD'deki 2016 başkanlık seçiminden önce -gerçeklik 
kontrol web sitelerinin belirlediği- yalan haberlerin tüketimini ve yalan haberlerin oy verme davranışlarına olası etkilerini incelemişler ve yalan haberlerin hakikatin hakeminin kimler olduğu hakkında önemli soruları da gündeme getirdiğini vurgulamışlardır. Sosyal medyanın yalan haberin dolaşımındaki rolü bağlamında Türkçe alan yazınında da konu tartışılmıştır. Kavakı (2019), sosyal medya üzerinden yayılan yalan haberle mücadele yöntemlerini ve yalan haberle mücadelede internet haber teyit/doğrulama platformlarının rolünü irdelemiştir. Taş ve Taş (2018) yalan haber sorununu yalan haberin sosyal medyada yaygınlaşması ve post-truth rejimini yeniden üreten bir boyut kazanması bağlamında değerlendirmişlerdir. Yazarlar, propagandanın, nefret söyleminin ve salt kendisini olumlamaya dayalı post-truth siyasetinin merkezinde olan yalan haber olgusunu Teyit.org'un "Suriyeli mülteciler" hakkında tespit ettiği yalan haberler üzerinden inceleyerek bu içeriklerin temalarını analiz etmişler ve "Suriyeli mültecilerle" ilgili yaygın düşünme biçimlerinin nasıl üretildiğini göstermişlerdir.

Bu çalışmada ise, yeni medya üzerinden yayılan yalan içerikler aracılığıyla post-truth siyasetin nası inşa edildiği 31 Mart 2019 yerel seçimi örneği üzerinden incelenmiştir. Çalışmanın amacı, haber sitelerinde ve sosyal ağlarda 31 Mart 2019 yerel seçimi sürecinde yayılan yalan içeriklerin yoğunluğunu, hangi mecralarda ne şekilde üretildiğini, etkileşim düzeyini ve temalarını ortaya koyarak bir anlamda yalan haberlerin haritasını çıkarmaktır. Bu amaçla, bir doğrulama platformu olan Teyit.org tarafından 31 Mart 2019 yerel seçim döneminde tespit edilen yalan içerikler ${ }^{4}$ amaçlı örneklem yöntemine göre seçilmiş ve belirlenen nicel ve nitel kategoriler üzerinden incelenmiştir. Amaçlı örnekleme, bir konunun detaylı araştırılması veya seçilen duruma bağlı olarak farkIı değişkenler arasında ilişki kurmayı amaçlayan çalışmalarda sıklıkla başvurulan bir yöntemdir (Büyüköztürk vd., 2018: 92).

Araştırmanın örneklemini oluşturan yalan haberler nicel ve nitel içerik analizi yöntemi kullanılarak iki boyutlu olarak analiz edilmiştir. İçerik analizinin birinci düzeyinde yeni medya üzerinden üretilen yalan içeriklerin frekans dağılımı ve mecralara göre etkileşim düzeyleri gibi nicel verileri değerlendirilmiş, ikinci düzeyinde ise içerikler, Teun van Dijk'ın (2000: 62-85) geliştirmiş olduğu kendini olumlu sunma, ötekini olumsuz sunma, biz-onlar ayrımı yapma (kutuplaştırma) ve kanıt gösterme gibi ideolojik çözümleme kategorileri referans alınarak temalarına göre ayrıştırılmış ve böylece yalan içeriklerin baskın temaları tespit edilmeye çalışılmıştır. Ancak, burada yalan haberlerin eleştirel söylem analizi yöntemiyle analiz edilmediğini, bu kategorilerin sadece yalan içeriklerin temalarının belirlenmesinde kullanıldığını belirtmekte yarar vardır. Bu temalar, nihai aşamada içerik analizi perspektifinden nicel verilere dönüştürülerek analiz edilmiştir. Nitel içerik analizinde içeriklerin kodlanmasında van Dijk'ın ideolojik çözümleme kategorilerinin kullanılmasının nedeni, internette ve sosyal medyada yayılan yalan haberlerin ne amaçla üretildiğini belirleyebilmektir. 


\section{Post-Truth Çă̆ı}

The Economist dergisi Eylül 2016 'da dünyanın “doğruluk sonrası siyaset” çağına girdiğini ilan etmiştir. Bu açıklamayı tetikleyen önemli olaylardan biri, Donald Trump'ın tartışmalı geçen seçim kampanyası olmuştur. Donald Trump, seçim sürecinde, sık olarak asılsız iddialar üzerinden yürüttüğü bir propaganda stratejisi yürütmüştür. Post-truth kavramını ve Donald Trump'ın seçim kampanyasını değerli kılan gelişme ise seçimin Trump'ın lehine sonuçlanmış olmasıdır (The post-truth world, 2016). Post-truth çağından bahsedilirken kavramın önüne getirilen 'post' ön eki, zamansal anlamda doğrunun ötesindeki bir çağı anlatmak için kullanılmamaktadır. Post-truth çağında, doğrunun ötesine geçmekten ziyade doğrunun önemsiz bir hale geldiği bir çağı anlatmak amacıyla 'post' ön eki kullanılmaktadır. Doğruluk sonrası bir çağa girildiğini anlatan bu kavrama göre, bireylerin bir şeye inanmalarını belirleyen bilimsel gerçekler yerini duygulara, ideolojilere ve siyasal ön yargılara bırakmıştır (Bezembinder, 2018: 45).

Post-truth kelimesini "doğruluk sonrası rejim" olarak tanımlayan Harsin (2015), kavramın gerçeklerin basit bir inmali sonucu çarptırılmasından ziyade politikacıların görünürlüklerinde ve katılımlarında etkili olabilecek kadar önemli olduğunu savunmaktadır. Harsin'e göre, birbirini izleyen yakın zamanlı gelişmelerin çoğu, hakikat sonrasının koşullarını meydana getirmiştir ve hakikat sonrasının oluşmasında etkili olan faktörler şu şekildedir (2015: 331):

- Medyanın parçalanması ve medyanın 'bekçi' görevini yerine getirmemesi,

- İnternet medyasında ünlenen bilgilerin izinin sürülmemesi,

- Profesyonelleşmiş halkla ilişkiler çalışmalarının manipülatif bir strateji izlemesi,

- Internet algoritmaları,

- Tıklama tuzakları (click bait),

- Ekonomik, teknolojik, sosyo- kültürel ve politik gelişmeler.

Harsin (2018), post-truth iletişim biçimini ve pratiklerini yapılandıran dört unsurdan bahsetmektedir. Bunlar; iletişim teknolojileri, gazetecilik, tüketim kültürü ve siyasal iletişimdir. Teknolojik gelişmeler aynı zamanda algı ve güven alanlarının yapılandırılmasında algoritmaların güçlü etkisini içermektedir. Özellikle, ideolojik filtreleme olarak çalışan yankı odaları buna bir örnektir. Gazeteciliğin gerçeği söyleme ve ayırt etme yetkisini yitirmesi ve tüketim kültürünün gazeteciliğe baskı uygulaması post-truth kültürünü etkilemiştir. Tüketim kültürü, kültür ve sosyal ilişkiler, iletişimin yeni tüketici kapitalizm biçimlerindeki rolüyle güçlü bir biçimde dönüştürülmüş ve dürüstlük algıları, gerçek iddiaları ve güven verme algıları değişikliğe uğramıştır. Diğer taraftan, siyasal iletişimde öne çıkan imaj yaratma ve siyasal pazarlama stratejileri de 'post-truth'a dayalı bir siyasal kültürü beslemiştir.

Avrupa Komisyonu'nun (2018) yalan haberleri ve çevrimiçi yayılan dezenformasyonu önlemek için politika girişimleri konusunda tavsiyelerde bulunmak üzere hazırladığı raporda beş önemli konuya vurgu yapılmış ve bu önlemler haberlerin şeffaflığını artırmak, medya okuryazarlığını teşvik etmek, kullanıcıları ve gazetecileri dezenformasyonun üstesinden gelmek için gelişen bilgi teknolojileri ile güçlendirmek, haber medyası ekosisteminin çeşitliliğini sağlamak ve dezenformasyonun etkisi üzerine yapılacak araştırmaları teşvik etmek şeklinde belirlenmiştir. Avrupa Komisyonu da post-truth ol- 
gusunu bir medya-okuryazarlığı konusu ve bir gazetecilik pratiğinden kaynaklanan bir sorun olarak bir eylem planı anlayışı içinde ele almıştır.

Fuchs (2018), post-truth kültürünü otoriter kapitalizmle ilişkilendirmekte ve Trump fenomenini otoriteryanizm kavramıyla açıklamaktadır. Buna göre, aşırı-sağ otoriter popülizmi anlamak için ekonomi-politiği, ideoloji eleştirisini ve eleştirel psikolojiyi birleştirerek bütünleştirici bir analiz çerçevesi önermekte ve bu çerçevede neoliberal kapitalizm biçimleri ile sağcı otoriterleşmenin yükselişi arasındaki bağlantıya dikkat çekmektedir. Otoriter popülizm duyguları, eğlence biçimleri ile sosyal medya üzerinden kamusal iletişim yoluyla çekmektedir. Bu bağlamda, kurumsal medya tekelleri ve medyanın magazinleşmesi post-truth siyasetin yükselişinde önemli bir rol oynamaktadır.

Wikforss (2020), iyi tasarlanmış çevrimiçi müzakere ortamını 'fake news (yalan haber)' ile mücadelenin bir yolu olarak görmekte ve 'yalan haber' olgusunu sadece bir içerik olarak değil, aynı zamanda bu içeriğin çevrimiçi ortamda dolaşma ve katılımcı kültüre aracılık etme biçimleri açısından da değerlendirmektedir. Bu noktada sorun sadece yanlış bilgi değil, aynı zamanda sosyal medya platformlarının bu tür yanlış bilgilerin üretimini ve yayılmasını nasıl teşvik ettiğidir. Bu nedenle yalan haberler propaganda gibi daha geleneksel yanlış bilgilendirme biçimlerinden farklıdır. Bu çevrimiçi sorun için çevrimiçi bir çözüm önerilmektedir. Çevrimiçi demokrasinin umutlu savunucuları, internette büyük bir potansiyel görmekte ve onu farklı toplumsal grupları bir araya getirebilecek yeni bir sanal kamusal alan olarak değerlendirmektedir. Ancak, Habermasyan bir bakışla, karşılıklılık ve yüz yüze etkileşim eksikliğinin olduğu internetin aracılı iletişim biçiminin müzakere ortamını zayıflattığı da unutulmamalıdır.

\section{Post- Truth Olgusunu Destekleyen Dijital Algoritmalar}

Politika ve medyada, duyguların nesnel gerçekliklerin önüne geçmesinde önemli bir faktör olan dijital algoritmalar, kişileri verisel hesaplamalara göre kategorilere ayırmakta ve her kategoriye özel içerikler sunmaktadır. Kamuoyunu ve partizanlığı şekillendiren bu algoritmalar, toplumun homojenleşmesine, insanların farklı düşüncelerden izole yaşamasına ve bir anlamda bireyin içine kapanmasına neden olmaktadır. Medya sahipleri ve iktidar güçleri lehine sonuçlar yaratan internet hesaplama metotları ve veri uygulamaları ile seçim dönemlerinde etkili bir stratejik iletişim sağlanmaktadır. Büyük verinin bir araya gelmesiyle güç kazanan internet platformları, bu haliyle kamuoyunun manipülasyonuyla görevli ajanlar gibidir (Woolley ve Guilbeault, 2017: 3-5).

Google ile birlikte interneti domine eden Facebook'un veri kaynağı, kullanıcılarının özel profil bilgileridir. Facebook kullanıcılarıyla ilgili çok fazla bilgi sunan bu veriler, kişilerin olumlu ve olumsuz tepki verebileceği ürünlere göre kullanılmaktadır. Hedefli bir yaklaşımla yürütülen bu iletişim safhasında, kullanıcılara kendi ilgi alanları dışında nadir içerik ya da ürün sunulmaktadır (Kramer vd., 2014: 8788).

Facebook'un kullanıcılarının profilleri üzerinden elde ettiği verileri üçüncü şahıslara satması sonucu patlak veren Cambridge Analitica Skandalı'nda kullanıcıların beğenilerine yönelik manipulatif içerikler, Brexit ve Amerika Birleşik Devletleri (ABD) baş- 
kanlık seçimi gibi kritik dönemlerde kişilerin seçim kararlarını etkilemek amacıyla kullanılmıştır. Küçük bir pazarlama şirketi olan Cambridge Analytica'nın geliştirmiş olduğu profil hedefleme aracıyla, başkanlık seçimi döneminde Trump seçmenlerini belirlediği ve Clinton aleyhine propaganda yaptığı ortaya çıkmıştır. Hedefli reklamcılık kapsamında ve reklam etiği ilkeleri çerçevesinde yorumlanan bu durum, demokratik yönetişimdeki bozulmanın sosyal medya ile bağlantılı olabileceğini gözler önüne sermiştir (Persily, 2017: 75).

Gerçekliğe inanma noktasındaki eğilimlerin arka planına bakıldığında geleneksel kanıt standartlarına meydan okuyan, bireysel bilişin başarısız olmasına yol açan teknolojik kaynakların varlığı görülmektedir. Bu nedenle, post-truth dönem değerlendirilirken yanlış bilginin yayılmasını engellemek için teknolojik dinamikleri tanımak oldukça önemlidir.

\subsection{Filtre Baloncukları (Filter Bubles)}

Partizan yaklaşımların artmasının ardındaki nedenlerden biri olarak görülen maruz kalma etkisinin, bireylerin inançları ve görüşleri üzerinde belirleyici olduğu düşünülmektedir. Bu mantığa göre, doğru ve nesnel inançların şekillenmesi, kişinin mevcut inançlarını ve görüşlerini zorlayan bilgilere bir dereceye kadar maruz kalmasıyla ilişkilidir. Sürekli aynı yönde beslemeye maruz kalan bireylerde taraftar olma ve toplumdan ayrılıp kendi topluluğunu kurma isteği söz konusudur (Stroud, 2010: 557). Ayrıca, insanların, özellikle azınlıktakiler için, kendi görüşlerinin gerçekte olduğundan daha geniş bir şekilde paylaşıldığını düşünme eğilimi vardır. İnternet kanallarındaki filtrelemenin etkilerine yönelik yapılan araştırmalarda, insanların bireysel farklılıklarına dair kanıtlara rastlanmıştır. Bazı insanlar kendi görüşleriyle paralel içeriklere ilgi gösterirken, bazıları için çekici olan, karşıt görüşlerin yer aldığı bir makale olabilmektedir. Aynı fikirlere sahip medya kanallarını takip edenler, algoritmaların sunduğu içerikleri umursamadıkları takdirde, alternatif görüşlere maruz kalabilmektedirler. Buna ek olarak, belirtilmesi gereken durum, aynı görüşlerin çekiciliğinin karşıt görüşlerin itici gücünden fazla olduğudur (Resnick vd., 2013:96-97).

Geleneksel medya ortamlarından ziyade internet teknolojilerinin yaygın olduğu yeni medya ortamında, insanların nelere maruz kalıp nelerden haberdar olmayacağını belirleyen algoritmalar bulunmaktadır. Pariser (2011: 10) tarafından "filtre balonu" olarak adlandırılan algoritmalar, internetin kalbindeki temel kodlardan biridir. Yeni nesil internet filtreleri, kişilerin sevdiği şeylere (internette yapılan her şeye) bakmakta ve tahminler yürütmektedir. Tahmin motorları olarak kullanılan bu algoritmalar; insanlara kim olduklarını, ne yapacaklarını ve ne isteyeceklerini bir teori yaratarak sunmaktadırlar. Bu motorlar, her bireyin fikir ve bilgi ile karşılaştığı yolda kişilere göre değişen kişiselleştirilmiş içeriklerin öne çıkmasını sağlamaktadır. ABD'de, 2016 yılında Donald Trump'ın başkan seçilmesinden sonra çok tartışılan bir konu haline gelen filtre baIonları, demokrasinin önündeki engellerden biri olarak görülmektedir. Özellikle, sistem odaklı haber kişiselleştirme teknolojileri, kullanıcıların önemli olma potansiyeli taşıyan birçok içerikten habersiz kalabilmelerine neden olmaktadır (Chen vd., 2017'den akt. Narin, 2018: 241). 


\subsection{Yankı Odası (Echo Chamber)}

Sosyal sınırların ortadan kalkması ve artan bilgi erişimi, insanlara farklı görüşler aramaları için geniş fırsatlar sunmaktadır. Kişisel ve sosyal yaşamımızın birçok yönüyle ilgili olan bu internet teknolojilerinin yarattığı fırsatlarla birlikte, yeni dünyada bilginin kontrolü yine bu teknolojilerin elindedir. Kişileri beğenecekleri ürün ve düşüncelerle karşılaştıran, karşıt olduklarından uzaklaştıran dijital algoritmalar, insanın bilgiye eriştiği yolda etken güçlerdir. Dijital algoritmaların insanları yalnızca kabul edip sevebileceği düşüncelerle karşılaştırdıkları bu alanlar, yankı odaları olarak adlandırımaktadır (Liao ve Tat Fu, 2014: 2745). Bu bağlamda, yankı odası (echo chamber) belirli bilgi, düşünce, kanaat ve inançların, kullanıcıların dijital medya kanallarında seçtikleri mesajlar aracılığıyla tekrarlanarak güçlendirilmesi durumunu anlatan metaforik bir terimdir (Narin, 2018: 240). Filtre balonları gibi yankı odaları da toplum nezdinde parçalanmalara ve gruplaşmalara neden olmaktadır. Karşıt düşüncelerden izole edilmiş yankı odalarında yalan içeriklerin sürekli bir biçimde dolaşımda olması, buna maruz kalan kitlenin gerçeğe ve doğru bilgiye ulaşmasını zorlaştırmaktadır.

\section{Araștırmanın Yöntemi}

Bu çalışma, haber sitelerinde ve sosyal ağlarda 31 Mart 2019 yerel seçimi sürecinde yayılan yalan içeriklerin yoğunluğunu, içeriklerin hangi mecralarda ve ne şekilde üretildiğini ve post-truth siyasetin hangi stratejilerle işlediğini üretilen içeriklerin temaları üzerinden ortaya koymayı amaçlamaktadır. Post-truth kavramının, ABD başkanlık seçimi ve Brexit oylamalarındaki etkisi göz önüne alındığında, siyasetin yeni gerçekliğinin oluşturan post-truth olgusunun Türkiye'deki 2019 yerel seçimi örneği üzerinden ele alınmasının siyasal iletişim çalışmalarına katkı sağlayacağı düşünülmüştür. Bu amaçla, 31 Mart 2019 yerel seçimi sürecinde internet haber siteleri, Facebook ve Twitter üzerinden yayılan yalan içerikler içerik analizi yöntemiyle incelenmiştir. İçerik analizi, bir metnin veya imgenin sistematik olarak incelenmesine dayanan, tekrarlanabilir ve geçerli çıkarımlar yapmayı sağlayan bir analiz (Aziz, 2008) olması ve incelenen iletişim içeriğinin bütünün özelliklerini göstermesi bakımından betimleyici bir niteliğe sahiptir. İçerik analizi, bu betimleyici niteliğinin sosyal değişimi incelemeye olanak sağlaması (Atabek ve Atabek, 2007) nedeniyle bu çalışma için uygun bir araştırma yöntemi olarak benimsenmiştir.

Araştırma, seçim takviminin başlangıcı olan 1 Ocak-1 Mayıs 2019 tarihleri arasındaki dört aylık süreyi kapsamaktadır. Seçimden sonraki bir ayın incelenmesinin nedeni, İstanbul seçiminin yarattığı belirsizlikten dolayı bu dönemde yalan haberlerin artmış olmasıdır. Araştırmanın örneklemi ise "internette yer alan şüpheli bilgileri tarayan, seçen, araştıran ve analiz haline getirerek okura sunan bir doğrulama platformu" olan Teyit.org tarafından 31 Mart 2019 yerel seçim dönemini kapsayan ve yanlış olduğu ispat edilen içeriklerden oluşmaktadır. Teyit.org tarafından derlenen yalan içerikler arasından amaçı̈ı örneklem yöntemine göre seçilen 32 yalan içerik öncelikle, içeriğin yayılma kaynağı, içeriğin yayılma zamanı, içeriğin ne şekilde oluşturulduğu, içeriğin türü, işlevi ve içeriğin yayılma nedeni şeklinde frekans analizine tabi tutulmuştur. Ardından araştırmanın ikinci bölümünde bu içerikler, Teun van Dijk'ın (2000) ideolojik söylem 
kategorilerine göre ayrıştırılarak içeriğin söylemsel stratejisi bağlamında incelenmiştir. Ayrıca, bu içerikler yeni medya ortamında etkileşim alma düzeylerine göre analiz edilmiş, böylece yalan içeriklerin ne kadar görünür olabildiği ve bunun anlamı üzerine çıkarımlar yapılmıştır. Bu çalışmada şu sorulara yanıt aranmıştır:

1- Yalan içerikler yeni medya üzerinden nasıl yayılmaktadır?

1.1. Yalan içerikler en çok hangi mecra üzerinden yayılmaktadır?

1.2. Yalan içerikler ne şekilde üretilmektedir?

1.3. Yalan içerikler en çok ne zaman yayılmaktadır?

1.4. Yalan içerikler hangi amaçla yayılmaktadır?

1.5. Yalan içeriklerin yanlışlığı teyit edildiğinde aynı içerikler yayında kalmaya devam etmekte midir?

2- Yalan içeriklerin temel söylemsel stratejisi nedir?

3- Mecralara göre en çok etkileşim alan içerikler hangileridir ve bunların temel özellikleri nelerdir?

31 Mart 2019 yerel seçim döneminde Facebook, Twitter ve internet haber siteleri üzerinden yayılan ve Teyit.org tarafından belirlenen yalan içerikleri post-truth siyaset anlayışı çerçevesinden değerlendiren bu araştırmadaki analiz ve bulgular sadece amaçlı örnekleme dahil edilen 32 veri ile sınırlıdır.

\section{Bulgular ve Yorum}

\subsection{Yalan İceriklerin Frekans Analizi}

Bu bölümde, yalan içeriklerin frekans dağılımlarına yer verilmiştir.

Tablo 1. Yalan İçeriklerin Frekans Analizi

\begin{tabular}{|c|c|c|}
\hline & Frekans & $\%$ \\
\hline \multicolumn{3}{|l|}{ İçeriğin Yayımlandığı Ortam } \\
\hline Facebook & 19 & 59,4 \\
\hline Twitter & 7 & 21,9 \\
\hline İnternet haber siteleri & 6 & 18,8 \\
\hline \multicolumn{3}{|l|}{ İçeriğin Yayınlanma Zamanı } \\
\hline Seçimden önce & 13 & 40,6 \\
\hline Seçimden sonra & 19 & 59,4 \\
\hline \multicolumn{3}{|l|}{ İçeriğin Türü } \\
\hline Yalan/yanlış bilgiler içeren metin & 16 & 50,0 \\
\hline Montajlı görüntü & 12 & 37,5 \\
\hline Montajlı video & 4 & 12,5 \\
\hline \multicolumn{3}{|l|}{ İçeriğin Amacı } \\
\hline Olumsuz imaj oluşturma & 11 & 34,4 \\
\hline
\end{tabular}




\begin{tabular}{|l|c|c|}
\hline İnfial yaratma & 10 & 31,3 \\
\hline Dikkat çekme & 4 & 12,5 \\
\hline Olumlu imaj oluşturma & 4 & 12,5 \\
\hline Suni gündem yaratma & 2 & 6,3 \\
\hline Sinyal verme/ nabız yoklama & 1 & 3,1 \\
\hline İçerik Yayında mı? Değil mi? & & \\
\hline İçerik yayında & 26 & 81,3 \\
\hline İçerik kaldırıldı & 6 & 18,8 \\
\hline Toplam & 32 & 100,0 \\
\hline
\end{tabular}

Araştırmanın örneklemini oluşturan 32 yalan içeriğin yayılma kaynaklarına bakıldığında, ilk sırada Facebook'un (19) yer aldığı, Facebook'u Twitter'ın (7) takip ettiği ve üçüncü sırada ise internet haber sitelerinin (6) yer aldığı görülmektedir. Yalan içerikler, yanlış bilgi alınmasından kaynaklı dolaşıma girebileceği gibi tamamen kötü bir niyetle yalan bilginin yayılması amacını da gütmektedir. Özellikle seçim dönemlerinde artan yalan içerikler, genel olarak propaganda amacına hizmet etmektedir.

Seçim sürecinde yayılan yalan içeriklerin seçimden önce mi sonra mı yayıldığını anlamak için yapılan analiz sonuçlarına göre, yalan içeriklerin en çok 31 Mart'tan sonra dolaşıma girdiği görülmektedir. Seçimden sonra üretilen içeriklerin (19), seçimden önce üretilen içeriklerden (13) fazla olmasının İstanbul yerel seçiminin tekrarlanması durumuyla ilişkili olduğu değerlendirilmiştir.

Yalan içeriklerin en fazla aldatıcı bilgilerden oluştuğu (16), bunu montajlı görüntülerin (12) ve videoların (4) takip ettiği, içeriğin yayılma amacına göre yapılan analiz sonuçlarına göre ise üretilen içeriklerin en çok olumsuz imaj yaratmaya (11) yönelik olduğu görülmektedir. Olumsuz imaj yaratmayı sırasıyla takip eden içerikler; infial yaratma (10), dikkat çekme (4), olumlu imaj yaratma (4), suni gündem oluşturma (2) ve sinyal verme/ nabız yoklama (1) şeklinde olmuştur.

Bilgiler düzeltildikten sonra yayından kaldırılıyor mu, kaldırılmıyor mu, sorusunun yanıtı yalanların bilinçli olarak üretilip üretilmediğini göstermesi açısından önemlidir. Bu kapsamda yapılan analiz sonuçları, yalan içeriklerin düzeltildikten sonra büyük oranda yayında kaldığını (26), çok az bir bölümünün yayından kaldırıldığını (6) göstermiştir. Yayından kaldırılan içerikler değerlendirilirken ana kaynağın yaptığı paylaşım üzerinden gidilmiştir. Çünkü, viral olarak yayılan yalan içerikler başka kullanıcılar tarafından da yayılabilmektedir.

\subsection{Yalan İçeriklerin Söylemsel Stratejilere Göre Analizi}

Çalışmanın bu bölümünde analiz birimini oluşturan haberler temalarına göre kategorilere ayrılmış ve bir nicellikselleştirme sistemi oluşturmak için van Dijk'ın (2000:6981) geliştirmiş olduğu ideolojik analiz kategorilerinden yararlanılmıştır. Böylece, yalan içeriklerde baskın olan ve öne çıkan temaların ortaya çıkarılması amaçlanmıştır. Yalan 
içeriklerin temaları şu şekilde kategorilere ayrılmıştır (van Dijk, 2000:69-81):

- Ötekini olumsuz sunma: Ötekinin olumsuz özelliklerini öne çıkarma.

- Kanıt gösterme: Rakamlara veya yetkili kurumlara atıf verme.

- Kendini olumlu sunma: Kendinin olumlu özelliklerini öne çıkarma.

- Kutuplaştırma: Biz-onlar ayrımını vurgulama.

- Karşılaştırma: Biz onlar ayrımına dayandırma ve grup dışı olarak görülenlere olumsuz imada bulunma.

Araştırma örnekleminde yer alan yalan içeriklerin yoğunlaştığı temalar Tablo 2'de gösterilmiştir:

Tablo 2. Yalan İçeriklerin Söylemsel Stratejilere Göre Frekans Analizi

\begin{tabular}{|l|c|c|}
\hline İdeolojik Çözümleme Kategorileri & Frekans & Yüzde \\
\hline Ötekini Olumsuz Sunma & 16 & 50,0 \\
Uslamlama (kanıt gösterme) & 6 & 18,8 \\
Kutuplaştırma & 5 & 15,6 \\
Kendini Olumlu Sunma & 4 & 12,5 \\
Karşılaştırma & 1 & 3,1 \\
Toplam & $\mathbf{3 2}$ & $\mathbf{1 0 0 , 0}$ \\
\hline
\end{tabular}

İdeolojik analiz kategorilerine göre ayrılan içerikler değerlendirildiğinde, en fazla başvurulan stratejinin, ötekini olumsuz sunma (16) olduğu görülmüştür. Ötekini olumsuz sunmadan sonra, yalan içeriklerde en çok kullanılan stratejiler sırasıyla uslamlama (6), kutuplaştırma (5), kendini olumlu sunma (4) ve karşıllaştırma (1) şeklinde olmuştur.

\subsection{1. Ötekini Olumsuz Sunma Temalı İçeriklerin Analizi}

Ötekini olumsuz sunma teması içinde değerlendirilen içeriklerin analiz sonuçları Tablo 3'teki gibidir.

Tablo 3. Ötekini Olumsuz Sunma Temalı İçeriklerin Analizi

\begin{tabular}{|l|l|}
\hline \multicolumn{2}{|l|}{ “CHP, HDP ve İyi Parti'nin Ortak Seçim Afişi” } \\
\hline İçeriğin Yayımlandığı Ortam & Facebook \\
\hline İçeriğin Yayııma Zamanı & Seçimden Önce \\
\hline İçeriğin Türü & Montajlı Görüntü \\
\hline İçeriğin Amacı & Olumsuz İmaj Oluşturma \\
\hline İçerik Yayında mı/ Kaldırıldı mı? & Yayında \\
\hline “HDP, Antalya'da Millet İttifakı'nı Destekliyor” \\
\hline İçeriğin Yayımlandığı Ortam & Facebook \\
\hline İçeriğin Yayııma Zamanı & Seçimden Önce \\
\hline İçeriğin Türü & Montajlı Görüntü \\
\hline
\end{tabular}




\begin{tabular}{|c|c|}
\hline İçeriğin Amacı & Olumsuz İmaj Oluşturma \\
\hline İçerik Yayında mı/ Kaldırıldı mı? & Yayında \\
\hline \multicolumn{2}{|c|}{ “CHP Adayı Mustafa Bozbey Kumarhanede” } \\
\hline İçeriğin Yayımlandığı Ortam & Facebook \\
\hline İçeriğin Yayılma Zamanı & Seçimden Önce \\
\hline İçeriğin Türü & Montajlı Görüntü \\
\hline İçeriğin Amacı & Olumsuz İmaj Oluşturma \\
\hline İçerik Yayında mı/ Kaldırıldı mı? & Yayında \\
\hline \multicolumn{2}{|c|}{ “Karayazı’da Jandarma Ak Parti’ye Oy Vermeleri İçin Vatandaşları Tehdit Etti” } \\
\hline İçeriğin Yayımlandığı Ortam & Facebook \\
\hline İçeriğin Yayılma Zamanı & Seçimden Önce \\
\hline İçeriğin Türü & Montajlı Görüntü \\
\hline İçeriğin Amacı & İnfial Yaratma \\
\hline İçerik Yayında mı/ Kaldırıldı mı? & Yayında \\
\hline \multicolumn{2}{|c|}{ “HDP’nin “Oylar CHP'ye Bizler Belediyeye” Afişi } \\
\hline İçeriğin Yayımlandığı Ortam & Facebook \\
\hline İçeriğin Yayılma Zamanı & Seçimden Önce \\
\hline İçeriğin Türü & Montajlı Görüntü \\
\hline İçeriğin Amacı & Olumsuz İmaj Oluşturma \\
\hline İçerik Yayında mı/ Kaldırıldı mı? & Yayında \\
\hline \multicolumn{2}{|c|}{ “CHP’li Belediye Kartal'a Haç Dikti” } \\
\hline İçeriğin Yayımlandığı Ortam & Facebook \\
\hline İçeriğin Yayılma Zamanı & Seçimden Sonra \\
\hline İçeriğin Türü & Yalan Bilgiler İçeren Metin \\
\hline İçeriğin Amacı & Olumsuz İmaj Oluşturma \\
\hline İçerik Yayında mı/ Kaldırıldı mı? & Kaldırıldı \\
\hline \multicolumn{2}{|c|}{ “FETÖ Tutuklusu Murat Kale, Ekrem İmamoğlu’nun Eski Ev Arkadaşı” } \\
\hline İçeriğin Yayımlandığı Ortam & Twitter \\
\hline İçeriğin Yayılma Zamanı & Seçimden Sonra \\
\hline İçeriğin Türü & Yalan Bilgi İçeren Metin \\
\hline İçeriğin Amacı & Olumsuz İmaj Oluşturma \\
\hline İçerik Yayında mı/ Kaldırıldı mı? & Yayında \\
\hline \multicolumn{2}{|c|}{ “'CHP'li Muhittin Böcek; Su ve Toplu Taşımaya Zam Yaptı, Evde Bakımı Kaldırdı' } \\
\hline İçeriğin Yayımlandığı Ortam & Facebook \\
\hline
\end{tabular}




\begin{tabular}{|c|c|}
\hline İçeriğin Yayılma Zamanı & Seçimden Sonra \\
\hline İçeriğin Türü & Yalan Bilgi İçeren Metin \\
\hline İçeriğin Amacı & Olumsuz İmaj Oluşturma \\
\hline İçerik Yayında mı/ Kaldırıldı mı? & Yayında \\
\hline \multicolumn{2}{|c|}{ “CHP’li Canan Kaftancıoğlu, Kandil’de” } \\
\hline İçeriğin Yayımlandığı Ortam & Facebook \\
\hline İçeriğin Yayılma Zamanı & Seçimden Sonra \\
\hline İçeriğin Türü & Montajlı Görüntü \\
\hline İçeriğin Amacı & İnfial Yaratma \\
\hline İçerik Yayında mı/ Kaldırıldı mı? & Kaldırıldı \\
\hline \multicolumn{2}{|c|}{ “CHP’li Mersin Büyükşehir Belediye'si Halk Ekmeği Kapattı” } \\
\hline İçeriğin Yayımlandığı Ortam & Facebook \\
\hline İçeriğin Yayılma Zamanı & Seçimden Sonra \\
\hline İçeriğin Türü & Yalan Bilgiler İçeren Metin \\
\hline İçeriğin Amacı & Olumsuz İmaj Oluşturma \\
\hline İçerik Yayında mı/ Kaldıııldı mı? & Yayında \\
\hline \multicolumn{2}{|c|}{ “Sezai Temelli, “'İstanbul ve Ankara’yı HDP yönetecek” dedi” } \\
\hline İçeriğin Yayımlandığı Ortam & İnternet Haber Sitesi \\
\hline İçeriğin Yayılma Zamanı & Seçimden Önce \\
\hline İçeriğin Türü & Yalan Bilgi İçeren Metin \\
\hline İçeriğin Amacı & Dikkat Çekme \\
\hline İçerik Yayında mı/ Kaldırıldı mı? & Yayında \\
\hline \multicolumn{2}{|c|}{ “Mahalleyi Bana Verin Ben De Size Vereyim Diyen Muhtar Aday } \\
\hline İçeriğin Yayımlandığı Ortam & Facebook \\
\hline İçeriğin Yayılma Zamanı & Seçimden Önce \\
\hline İçeriğin Türü & Montajlı Görüntü \\
\hline İçeriğin Amacı & Suni Gündem Oluşturma \\
\hline İçerik Yayında mı/ Kaldırıldı mı? & Yayında \\
\hline \multicolumn{2}{|c|}{ “Fatma Şahin “Ferhat Şirin'i Deldi” Dedi” } \\
\hline İçeriğin Yayımlandığı Ortam & Twitter \\
\hline İçeriğin Yayılma Zamanı & Seçimden Önce \\
\hline İçeriğin Türü & Montajlı Görüntü \\
\hline İçeriğin Amacı & Olumsuz İmaj Oluşturma \\
\hline İçerik Yayında mı/ Kaldıııldı mı? & Yayında \\
\hline
\end{tabular}




\begin{tabular}{|l|l|}
\hline \multicolumn{2}{|l|}{ “Manyas’ta AKP'nin İtirazlarıyla Başkanlık MHP'den CHP'ye Geçti” } \\
\hline İçeriğin Yayımlandığı Ortam & Twitter \\
\hline İçeriğin Yayılma Zamanı & Seçimden Sonra \\
\hline İçeriğin Türü & Yalan Bilgiler İçeren Metin \\
\hline İçeriğin Amacı & Dikkat Çekme \\
\hline İçerik Yayında mı/ Kaldırıldı mı? & Yayında \\
\hline “AKP, İstanbul Seçimlerinin İptali İçin Başvurdu” \\
\hline İçeriğin Yayımlandığı Ortam & İnternet Haber Siteleri \\
\hline İçeriğin Yayılma Zamanı & Seçimden Sonra \\
\hline İçeriğin Türü & Yalan Bilgiler İçeren Metin \\
\hline İçeriğin Amacı & Dikkat Çekme \\
\hline İçerik Yayında mı/ Kaldırıldı mı? & Yayında \\
\hline “Çocuğu Oımayana Çocuk Yapacağım Diyen Belediye Başkan Adayı” \\
\hline İçeriğin Yayımlandığı Ortam & Facebook \\
\hline İçeriğin Yayıma Zamanı & Seçimden Önce \\
\hline İçeriğin Türü & Montajı Görüntü \\
\hline İçeriğin Amacı & Olumsuz İmaj Oluşturma \\
\hline İçerik Yayında mı/ Kaldırılı mı? & Yayında \\
\hline
\end{tabular}

Ötekini olumsuz sunma kategorisinde yer alan yalan içeriklerin en fazla Facebook'ta (11) yer aldığı, montajlı görüntüyle (9) servis edildiği ve yayında (14) kalmaya devam ettiği görülmektedir. Bu veriler, yalan içeriklerin Facebook üzerinden yayılma eğiliminin daha güçlü olduğunu göstermektedir.

\subsubsection{Uslamlama (Kanıt Gösterme) Temalı İçeriklerin Analizi}

Araştırma kapsamında incelenen içeriklerden uslamlama (kanıtsallık) temalı içeriklerin analiz sonuçları Tablo 4'teki gibidir.

Tablo 4. Uslamlama Temalı İçeriklerin Analizi

\begin{tabular}{|l|l|}
\hline \multicolumn{2}{|l|}{ “İzmir Büyükşehir Belediyesi Seçim İçin Stok Patates Dağıttı” } \\
\hline İçeriğin Yayımlandığı Ortam & Facebook \\
\hline İçeriğin Yayııma Zamanı & Seçimden Önce \\
\hline İçeriğin Türü & Montajı Görüntü \\
\hline İçeriğin Amacı & Olumsuz İmaj Oluşturma \\
\hline İçerik Yayında mı/ Kaldırıldı mı? & Yayında \\
\hline “KOMSAR Araştırma Şirketi Sonuçları \\
\hline İçeriğin Yayımlandığı Ortam & İnternet Haber Siteleri \\
\hline İçeriğin Yayııma Zamanı & Seçimden Önce \\
\hline
\end{tabular}




\begin{tabular}{|c|c|}
\hline İçeriğin Türü & Yalan Bilgi İçeren Metin \\
\hline İçeriğin Amacı & Dikkat Çekme \\
\hline İçerik Yayında mı/ Kaldırıldı mı? & Yayında \\
\hline \multicolumn{2}{|c|}{ "Suruç'ta 4 Çuval Mühürlü Oy Pusulası” } \\
\hline İçeriğin Yayımlandığı Ortam & İnternet Haber Siteleri \\
\hline İçeriğin Yayılma Zamanı & Seçimden Sonra \\
\hline İçeriğin Türü & Yalan Bilgi İçeren Metin \\
\hline İçeriğin Amacı & Olumsuz İmaj Oluşturma \\
\hline İçerik Yayında mı/ Kaldırıldı mı? & Yayında \\
\hline \multicolumn{2}{|c|}{ “30 Sandık Başkanı Gözaltına Alındı” } \\
\hline İçeriğin Yayınlandığı Ortam & Facebook \\
\hline İçeriğin Yayılma Zamanı & Seçimden Sonra \\
\hline İçeriğin Türü & Yalan Bilgi İçeren Metin \\
\hline İçeriğin Amacı & İnfial Yaratma \\
\hline İçerik Yayında mı/ Kaldırıldı mı? & Kaldırıldı \\
\hline \multicolumn{2}{|c|}{ “Arnavutköy’de 1700 Oy Cumhur İttifakı'na Geçti” } \\
\hline İçeriğin Yayımlandığı Ortam & İnternet Haber Siteleri \\
\hline İçeriğin Yayılma Zamanı & Seçimden Sonra \\
\hline İçeriğin Türü & Yalan Bilgi İçeren Metin \\
\hline İçeriğin Amacı & İnfial Yaratma \\
\hline İçerik Yayında mı/ Kaldırıldı mı? & Yayında \\
\hline \multicolumn{2}{|c|}{ "Başkan Erdoğan'ın İmzaladığı Çok Gizli Belge” } \\
\hline İçeriğin Yayımlandığı Ortam & Facebook \\
\hline İçeriğin Yayılma Zamanı & Seçimden Sonra \\
\hline İçeriğin Türü & Montajlı Görüntü \\
\hline İçeriğin Amacı & İnfial Yaratma \\
\hline İçerik Yayında mı/ Kaldırıldı mı? & Yayında \\
\hline
\end{tabular}

Rakamsal verilerle kanıt göstermeye dayalı yalan içerikler Facebook (3) ve haber siteleri (3) üzerinden dolaşıma girmiş, bu içerikler daha çok metin (4) halinde yayımlanmış ve içerikler yayında (5) kalmaya devam etmiştir.

\subsubsection{Kutuplaștırma Temalı İçeriklerin Analizi}

Kutuplaştırma temalı içeriklerin analiz sonuçları Tablo 5’teki gibidir. 
Tablo 5. Kutuplaştırma Temalı İçeriklerin Analizi

\begin{tabular}{|c|c|}
\hline \multicolumn{2}{|c|}{ “Gaziosmanpaşa'da CHP Mühürlü Oy Pusulalarını Boşalttı” } \\
\hline İçeriğin Yayımlandığı Ortam & Twitter \\
\hline İçeriğin Yayılma Zamanı & Seçimden Sonra \\
\hline İçeriğin Türü & Montajlı Video \\
\hline İçeriğin Amacı & İnfial Yaratma \\
\hline İçerik Yayında mı/ Kaldırıldı mı? & İçerik Kaldırıldı \\
\hline \multicolumn{2}{|c|}{ "Binali Yıldırım'ın "Teşekkürler İstanbul” Afişinin Yanındaki Ekrem İmamoğlu Afişi”" } \\
\hline İçeriğin Yayımlandığı Ortam & Twitter \\
\hline İçeriğin Yayılma Zamanı & Seçimden Sonra \\
\hline İçeriğin Türü & Montajlı Görüntü \\
\hline İçeriğin Amacı & Suni Gündem Oluşturma \\
\hline İçerik Yayında mı/ Kaldırıldı mı? & Yayında \\
\hline \multicolumn{2}{|c|}{ "YSK Oyların Yeniden SayıImasına Karar Verdi" } \\
\hline İçeriğin Yayımlandığı Ortam & Facebook \\
\hline İçeriğin Yayılma Zamanı & Seçimden Sonra \\
\hline İçeriğin Türü & Yalan Bilgi İçeren Metin \\
\hline İçeriğin Amacı & Sinyal Verme/ Nabız Ölçme \\
\hline İçerik Yayında mı/ Kaldırıldı mı? & Yayında \\
\hline \multicolumn{2}{|c|}{ "Gaziosmanpaşa'da Sandıklar Vaktinden Önce Açıldı” } \\
\hline İçeriğin Yayımlandığı Ortam & Facebook \\
\hline İçeriğin Yayılma Zamanı & Seçimden Sonra \\
\hline İçeriğin Türü & Montajlı Video \\
\hline İçeriğin Amacı & İnfial Yaratma \\
\hline İçerik Yayında mı/ Kaldırıldı mı? & Yayında \\
\hline \multicolumn{2}{|c|}{ “Öldürülen Saadet Partililerin Fotoğrafı" } \\
\hline İçeriğin Yayımlandığı Ortam & Facebook \\
\hline İçeriğin Yayılma Zamanı & Seçimden Sonra \\
\hline İçeriğin Türü & Montajlı Görüntü \\
\hline İçeriğin Amacı & İnfial Yaratma \\
\hline İçerik Yayında mı/ Kaldırıldı mı? & Yayında \\
\hline
\end{tabular}

Kutuplaştırma temalı içeriklerin Facebook (3) ve Twitter (2) üzerinden yayıldığı ve daha çok montajı görüntü ve video (4) yoluyla üretildiği görülmektedir. 


\subsubsection{Kendini Olumlu Sunma Temalı İçeriklerin Analizi}

Kendini olumlu sunma temalı içeriklerin analiz sonuçları Tablo 6'daki gibidir.

Tablo 6. Kendini Olumlu Sunma Temalı İçeriklerin Analizi

\begin{tabular}{|c|c|}
\hline \multicolumn{2}{|c|}{ “Ekrem İmamoğlu, Hasan Ali Yücel’in Öz Yeğeni” } \\
\hline İçeriğin Yayımlandığı Ortam & Twitter \\
\hline İçeriğin Yayılma Zamanı & Seçimden Önce \\
\hline İçeriğin Türü & Yalan Bilgi İçeren Metin \\
\hline İçeriğin Amacı & Olumlu İmaj Oluşturma \\
\hline İçerik Yayında mı/ Kaldırıldı mı? & Yayında \\
\hline \multicolumn{2}{|c|}{ “Zeydan Karalar, Yolsuzluk Nedeniyle Mazbatasını Almadı” } \\
\hline İçeriğin Yayımlandığı Ortam & Facebook \\
\hline İçeriğin Yayılma Zamanı & Seçimden Sonra \\
\hline İçeriğin Türü & Yalan Bilgi İçeren Metin \\
\hline İçeriğin Amacı & Olumlu İmaj Oluşturma \\
\hline İçerik Yayında mı/ Kaldırıldı mı? & Yayında \\
\hline \multicolumn{2}{|c|}{ “Mansur Yavaş'ın Anıtkabir Hatıra Defterindeki El Yazısı” } \\
\hline İçeriğin Yayımlandığı Ortam & Twitter \\
\hline İçeriğin Yayılma Zamanı & Seçimden Sonra \\
\hline İçeriğin Türü & Yalan Bilgi İçeren Metin \\
\hline İçeriğin Amacı & Olumlu İmaj Oluşturma \\
\hline İçerik Yayında mı/ Kaldırıldı mı? & Yayında \\
\hline \multicolumn{2}{|c|}{ “Ekrem İmamoğlu’nun Mazbata Aldığını Gösteren Fotoğraf” } \\
\hline İçeriğin Yayımlandığı Ortam & İnternet Haber Siteleri \\
\hline İçeriğin Yayılma Zamanı & Seçimden Sonra \\
\hline İçeriğin Türü & Montajlı Görüntü \\
\hline İçeriğin Amacı & Dikkat Çekme \\
\hline İçerik Yayında mı/ Kaldırıldı mı? & Kaldırıldı \\
\hline
\end{tabular}

Kendini olumlu sunma temalı içeriklerin daha çok seçimden sonra (3) yayıldığı ve metin (3) yoluyla üretildiği görülmektedir.

\subsubsection{Karșılaștırma Temalı İçeriklerin Analizi}

Karşılaştırma temalı içeriklerin analiz sonuçları Tablo 7'deki gibidir. 
Tablo 7. Karşılaştırma Temalı İçeriklerin Analizi

\begin{tabular}{|l|l|}
\hline \multicolumn{2}{|l|}{ “Japonya’da Lise Mezunu OImayanlar Oy Veremiyor” } \\
\hline İçeriğin Yayımlandığı Ortam & Facebook \\
\hline İçeriğin Yayılma Zamanı & Seçimden Önce \\
\hline İçeriğin Türü & Yalan Bilgi İçeren Metin \\
\hline İçeriğin Amacı & İnfial Yaratma \\
\hline İçerik Yayında mı/ Kaldırıldı mı? & Yayında \\
\hline
\end{tabular}

Temalarına göre ayrıştırımış içeriklere ilişkin genel bir değerlendirme yapıldığında ötekini olumsuz sunma temasının öne çıktığını, yalan içeriklerin Facebook üzerinden daha fazla yayıldığını ve montajı görüntü ile desteklenerek etki gücünün artırımasının amaçlandığını söylemek mümkündür. Yalan içeriklerin yeni medya mecralarında daha geniş bir alan bulması kuşkusuz yeni medyanın yarattığı etki gücüyle de yakından bağlantılıdır.

\subsection{Mecralara Göre En Çok Etkileșim Alan İçeriklerin Analizi}

İnternet tabanlı mecralardan yayılan içeriklerin etkileşimlerini tespit etmek, bu içeriklerin ne kadar dikkat çektiğini göstermek açısından önemlidir. Sosyal medya mecralarında genel olarak paylaşılan içeriklerde en çok ses getirenler duygulara hitap edenler olmaktadır. Yalan içeriklerin de en az bir duyguyu (öfke, nefret, sevgi vb.) tetikleyecek şekilde üretildiği düşünüldüğünde, yalan içeriklerin neden bu kadar yayıldığını anlayabilmek daha da kolaylaşmaktadır.

Bu analizde kullanılan veriler için Teyit.org'un her yıl düzenli olarak yayınladığı yalan haber karnesi ${ }^{5}$ kullanılmış ve mecralara göre en çok etkileşim alan 5 yalan içeriğe ilişkin veriler Tablo 8'de sunulmuştur.

Tablo 8. Mecralara Göre En Çok Etkileşim Alan 5 İçerik

\begin{tabular}{|l|c|}
\hline En Çok Etkileşim Alan 5 İçerik & Etkileşim \\
\hline FACEBOOK & 52.953 \\
\hline Japonya'da Lise Mezunu OImayanlar Oy Veremiyor İddiası & 21.946 \\
\hline Ekrem İmamoğlu, Hasan Ali Yücel'in Öz Yeğeni İddiası & 21.271 \\
\hline $\begin{array}{l}\text { Gaziosmanpaşa'da CHP'lilerin Mühürlü Oy Pusulalarını } \\
\text { Boşaltı̆̆ı İddiası }\end{array}$ & 19.750 \\
\hline $\begin{array}{l}\text { Mansur Yavaş'ın Anıtkabir Hatıra Defterindeki El Yazısı } \\
\text { İddiası }\end{array}$ & 16.018 \\
\hline Gaziosmanpaşa'da Oyların Çalındığı İddiası & \\
\hline
\end{tabular}

5 Sahte Haber Karnesi, https://teyit.org/wp-content/uploads/2019/05/Rapor-YS-2019-1.pdf, Erişim Tarihi: 18.06.2019. 


\begin{tabular}{|c|c|}
\hline \multicolumn{2}{|l|}{ TWITTER } \\
\hline $\begin{array}{l}\text { Zeydan Karalar, Yolsuzluk Nedeniyle Mazbatasını Almadığı } \\
\text { İddiası }\end{array}$ & 88.952 \\
\hline $\begin{array}{l}\text { Manyas'ta AKP'nin İtirazlarıyla Başkanlığın MHP'den } \\
\text { CHP'ye Geçtiği İddiası }\end{array}$ & 82.139 \\
\hline Japonya'da Lise Mezunu OImayanlar Oy Veremiyor İddiası & 36.318 \\
\hline $\begin{array}{l}\text { Fatma Şahin'in konuşmasında "Ferhat Şirin'i Deldi" } \\
\text { Dediğinin İddiası }\end{array}$ & 36.210 \\
\hline $\begin{array}{l}\text { Binali Yıldırım'ın “Teşekkürler İstanbul”Afişinin Yanındaki } \\
\text { Ekrem İmamoğlu Afişi İdidası }\end{array}$ & 25.066 \\
\hline \multicolumn{2}{|l|}{ INTERNET } \\
\hline $\begin{array}{l}\text { Zeydan Karalar, Yolsuzluk Nedeniyle Mazbatasını Almadığı } \\
\text { İddiası }\end{array}$ & 103.380 \\
\hline $\begin{array}{l}\text { Manyas'ta AKP'nin İtirazlarıyla Başkanlığın MHP'den } \\
\text { CHP'ye Geçtiği İddiası }\end{array}$ & 89.385 \\
\hline Japonya'da Lise Mezunu OImayanlar Oy Veremiyor İddiası & 89.271 \\
\hline $\begin{array}{l}\text { Fatma Şahin'in konuşmasında "Ferhat Şirin'i Deldi" } \\
\text { Dediğinin İddiası }\end{array}$ & 47.902 \\
\hline $\begin{array}{l}\text { Mansur Yavaş'ın Anıtkabir Hatıra Defterindeki El Yazısı } \\
\text { İddiası }\end{array}$ & 41.273 \\
\hline
\end{tabular}

Yeni medya mecralarında yayılan yalan içerikler arasından en çok etkileşim alan haberlerin haber sitelerinde ve Twitter'da yayıldığı görülmektedir. Etkileşim düzeylerine bakıldığında yalan içeriklerin oldukça geniş bir zemin bulduğu söylenebilir. Etkileşim düzeyi haberin paylaşılması ve tıklanması gibi nicel veriler üzerinden aslında ne kadar ilgi çektiğini ve ne büyüklükte bir okuyucu/izleyici kitlesine ulaştığını göstermesi açısından önemli bir veri sunmaktadır. En çok etkileşim alanların aslında şaşkınlık uyandıran ve siyaset aklının olağan akışına uymayan içerikler olduğu görülmektedir. Bu içeriklerin geniş bir alanda görünürlük kazanması, bunları okuyanların inandığı ve kabul ettiği anlamına gelmemektedir; ancak, gerçek dışıı̆̆ın ne kadar geniş bir zemin bulabildiğini göstermesi açısından önemlidir.

\section{Sonuç}

İnternette dolaşan uydurma ve tuhaf haberler, halkta duyuşsal bir yanıtı tetiklemek için tasarlanmış bir ajitasyon propagandası olarak işlev görmektedir (Khaldarova ve Pantti, 2016). Yalan haberin olguları itibarsız kılarak siyasetin zeminini inanç ve duygulara kaydırma işlevi, olgusal gerçekliği ve rasyonelliği de felce uğratmaktadır (Taş ve Taş, 2018). Yalan haber olgusu, siyasal iletişim süreçlerini koşullandıran ve belirleyen yeni bir sorun olarak hem medya hem de siyaset etiğini yeniden düşünmemiz gerektiğini göstermektedir. İnternet ortamında üretilen sayısız içeriğin, çok geniş kitlelere ulaşması ve çok sayıda bilgiye maruz kalan bireylerin bunlar arasından ayrım yapmakta zorlanması, hakikatin değersizleşmeye başlamasını tetikleyen önemli dinamikler arasındadır. Henry Jenkins tarafından "katııımc kültür yarattığına inanılan sosyal medya 
mecralarının" (Jenkins, 2008'den akt. Fuchs, 2014: 79) yalan içeriklerin yayılmasında aktif rol oynadığı görülmektedir. Herkesin istediği şekilde paylaşım yaptığı bu mecralarda paylaşımların doğruluğunun kontrol edilmemesi beraberinde viral olarak yayılacak yalan içeriklere inananlar kümesini doğurmaktadır.

Post-truth çağını yani hakikatin değersizleşmesini öne çıkaran bir diğer faktör de internet teknolojilerinin daha fazla ekonomik çıkar elde etmeye yönelik uygulamalarıdır. Kullanıcıların ilgi alanlarına yönelik içeriklerle karşılaşmasını kullanıcı yararına dayandıran Google ve Facebook gibi internetin egemen güçleri, aslında daha fazla ekonomik çıkar sağlamayı önemsemektedir. Yalan içeriklerin birincil kaynağı olarak ilk sırayı alan Facebook için kullanıcı verileri, büyük reklam şirketlerine satılmak için kullanılan metalardır. Bu yüzden, kullanıcı eğilimlerini doğru bir şekilde analiz eden bu dev mecra, özünde kullanıcı deneyimini savunsa da madalyonun öteki yüzünde ekonomi-politik dinamikler bulunmaktadır.

31 Mart 2019 yerel seçim sürecinde üretilen yalan içeriklerin yoğunluğunu ve hangi temalarla ne şekilde yayıldığını göstermeyi amaçlayan bu çalışmanın sonuçları seçim dönemlerinde üretilen içeriklerin yoğun olarak ötekini olumsuz sunma temasını içerdiğini göstermiştir. İkinci yaygın kategori olan uslamlama, yalan içeriklerde kullanılan gerçek dışı kanıtlar üzerinden yapılmıştır. Sayısal verileri kullanmanın inandırıcılığı artıracağı düşüncesiyle bu içeriklerde, metinler genellikle rakamlarla desteklenmiştir. Kanıt gösterme temalı içeriklerin de aslında ötekini olumsuz sunma amacını taşıdığı söylenebilir. Üçüncü kategori ise kutuplaştırmadır. Kutuplaştırma da yalan içeriklerin en göze çarpan temalarından biri olmuştur. Yalan içeriklerin en çok hangi kanallardan yayıldığına ilişkin bulgular Facebook'un önde olduğunu göstermiştir. Yalan içeriğin yayılma kaynağında Facebok'tan sonra gelen Twitter ise etkileşim oranlarında Facebook'un önüne geçmiştir. Buna göre, Twitter'ın siyasal iletişim sürecinde diğer mecralardan daha etkili olduğunu söylemek mümkündür.

Etkileşim oranlarında en etkili mecranın Twitter olması akıllara Fuchs'un (2014) "Twitter, bir kamusal alan yaratılmasına katkıda bulunur mu?” sorusunu getirmektedir. Bu açıdan bakıldığında, Twitter'ın yeni bir kamusal alan yaratmaktan öte, yalan içeriklerin yoğun olarak dolaşımda olduğu bir bilgi çöplüğü yarattığını söylemek daha doğru olacaktır. Elbette, bu durumun tüm Twitter içerikleri için geçerli olduğu iddia edilemez. Twitter kullanıcıları üzerine yapılan bir araştırmada, Twitter'da faaliyet gösteren bireylerin \%80'inin kendi hayatları ve düşünceleriyle ilgili bir tavır içinde oldukları görülmüştür (Ott, 2017: 60). Burada bahsedilen, Twitter üzerine yapılan araştırma sonuçlarında da görülen \%20'lik grubun haber tüketim davranışlarıdır.

Ayrıca, araştırmanın bir diğer sonucu ise, yalan içeriklerin 31 Mart 2019 tarihinden sonra daha fazla yayılması, doğruluk kontrol merkezleri tarafından yanlışlandığı halde çoğunun yayında kalması ve seçim döneminde karşı taraf hakkında olumsuz imaj yaratma amacıyla kullanılmış olmasıdır. Yeni medya üzerinden yayılan yalan içeriklerin kontrolsüz bir şekilde yayılması, gerçeğin görünürlüğünü de yok edecektir. Siyasi aktörlerin kendi çıkarları için başvurduğu manipülatif söylemler post-truth çağında daha kolay işlerlik kazansa da bu durumun uzun vadede toplumsal bozulmalara yol açacağı düşünülmektedir. Post-truth çağında üretilen içeriklerin doğruluk teyidine gereken 
önem verilmediği takdirde sadece rakip siyasi liderler değil, yurttaşlar da manipülatif söylemler yaratmaya yönelecektir.

Bu nedenle, bu çevrimiçi sorunun çevrimdışı bir çözüme ihtiyacı olup olmadığını da değerlendirmek gerekmektedir. Bu noktada katılımcı demokrasi bir çözüm önermektedir. Kişilerin akıl yürütme biçimlerini sosyal ortamlarda tasarlandığı gibi kullanması için daha fazla fırsatı olması, yalan haberlere daha az duyarlı olmasını sağlayacaktır. Bunlar, müzakereci forumlar veya yurttaş toplantıları şeklinde olabilir. Bu tür faaliyetlere daha fazla katılım, kişileri daha aktif muhakeme ve değerlendirmeye dayanan bilgi toplama yöntemlerine doğru yöneltecektir. Bu yüz yüze forumlarda müzakere etmek, kutuplaşmış gruplar arasındaki sınırları yıkarken halkı bilgi ile aşılamak için güçlü bir araç olabilir. Çevrimiçi demokrasiyi geliştirmeyi ve yalan haberlerle mücadele etmeyi amaçlayan politikalar elbette yanlış bilgilendirme düzenlemeleri ile ilgili çevrimiçi çözümleri dikkate almalıdır, ancak daha geniş bir perspektif almak ve kutuplaşma ile mücadele etmek ve bazılarını bozmak için hangi katılımcı modellerin kullanılabileceği üzerinde durmak önemlidir. Kamusal müzakere bireylerin kendilerini yalan haberlere karşı koruma yeteneğini artıran bir çözüm olarak düşünülmelidir (Wikforss, 2020).

Bu bağlamda, yeni medya ortamındaki bütün platformların doğruluk teyit mekanizmalarıyla birlikte çalışması bir çözüm olarak önerilebilir. Haber siteleri ve sosyal medya kanallarının doğruluk kontrol platformlarıyla yaptıkları anlaşmalar daha güçlü maddelerle desteklenmeli ve ciddi kontroller sağlanmalıdır. Post-truth siyaset bağlamında yeni medyanın rolünü ve içeriklerin niteliğini anlamaya yönelik bu çalışma genel bir durum tespiti niteliğindedir. Bu konuda çalışma yapmak isteyen araştırmacıların, işin kullanıcı boyutuna da odaklanması ve yalan içeriklerin tüketimine yönelik eğilimleri belirlemeye çalışması post-truth çağında siyaset ve yeni medya ilişkilerini anlamada önemli katkılar sağlayacaktır.

\section{Kaynakça}

Allcott, H. ve Gentzkow, M. (2017). Social Media and Fake News in the 2016 Election. Journal of Economic Perspectives, Volume 31, Number 2, ss. 211-236, https://pubs.aeaweb.org/doi/ pdfplus/10.1257/jep.31.2.211, Erişim tarihi: 15.02.2020.

Atabek, G. Ş. ve Atabek, Ü. (2007). Medya Metinlerini Çözümlemek. Ankara: Siyasal Kitabevi. Aziz, A. (2008). Sosyal Bilimlerde Araştırma Yöntemleri ve Teknikleri. Ankara: Nobel Yayın Dağıtım.

Bezembinder, C. (2018). Is Post- Truth Politics Really Post- Truth?. Master Thesis, Leiden: Leiden University.

Bilgin, P. (2017). Resisting Post-truth Politics, a Primer: Or, How Not to Think about Human Mobility and the Global Environment, Global Policy, Volume 8, Supplement 1, 55-59, https:// onlinelibrary.wiley.com/doi/epdf/10.1111/1758-5899.12411

Büyüköztürk, Ş., Akgün, Ö. E., Demirel, F., Karadeniz, Ş. ve Çakmak, E. K. (2015). Bilimsel Araştırma Yöntemleri. Ankara: Pegem Akademi. 
Fuchs, C. (2018). Authoritarian capitalism, authoritarian movements and authoritarian communication, Media, Culture \& Society, Volume: 40 Issue: 5, page(s): 779-791, https://doi. org/10.1177/0163443718772147

Fuchs, C. (2014). Sosyal Medya Eleştirel Bir Giriş. (I. Kalaycı ve D. Saraçoğlu, Çev.), Ankara: NotaBene.

Gross, M. (2017). The Dangers of a Post-Truth World. Current Biology, 27 (9), 1-18.

Harsin, J. (2018). Post-truth and critical communication. İcinde: Oxford Research Encyclopedia of Communication. Oxford University Press. doi: http://dx.doi.org/10.1093/ acrefore/9780190228613.013.757

Harsin, J. (2015). Regimes of Post- Truth, Post- Politics, and Attention Economies, Communication, Culture \& Critique, 8(2), 327-333.

Higgins, K. (2016). Post-truth: a guide for the perplexed, Nature 540,9, (01 December 2016), doi:10.1038/540009a

Kavaklı, N. (2019). Yalan Haberle Mücadele ve İnternet Teyit/Doğrulama Platformları. Erciyes Iletişim Dergisi, Cilt 6, Sayı 1, ss. 663-682, https://dergipark.org.tr/en/download/articlefile/630656, Erişim tarihi: 15.02.2020.

Kavanagh, J. ve Rich, M. D. (2018). Truth Decay: An Initial Exploration of the Diminishing Role of Facts and Analysis in American Public Life. Santa Monica, CA: RAND Corporation, 2018. https://www.rand.org/pubs/research_reports/RR2314.html.

Khaldarova, I. ve Pantti, M. (2016). Fake News, Journalism Practice, 10:7, 891901, DOI: 10.1080/17512786.2016.1163237

Kellner, D. (2018), Donald Trump and the Politics of Lying. Michael A. Peters, Sharon Rider, Mats Hyvönen, Tina Besley (Eds.) Post-Truth, Fake News, Singapore: Springer.

Keyes, R. (2017). Hakikat Sonrası Çağ: Günümüz Dünyasında Yalancılık ve Aldatma (D. Özçetin, Çev.), İzmir: Tudem.

Kollanyi, B., Howard, P. N., Woolley, S. C. (2016), Bots and Automation over Twitter During the US Election. Data Memo. Oxford, UK: Project on Computational Propaganda, (4), 1-5.

Kramer, A. D., Guillory, J. E., Hancock, J. T. (2014). Experimental evidence of Massive-Scale Emotional Contagion Through Social Networks. Proceedings of the National Academy of Sciences, 111(24), 8788-8790.

Liao, Q. V., Fu, W. T. (2014, April). Expert Voices in Echo Chambers: Effects of Source Expertise Indicators on Exposure to Diverse Opinions. In Proceedings of the SIGCHI Conference on Human Factors in Computing Systems (pp. 2745-2754). ACM.

Narin, B. (2018). Kişiselleştirilmiş Çevrimiçi Haber Akışının Yankı Odası Etkisi, Filtre Balonu ve Siberbalkanizasyon Kavramları Çerçevesinde İncelenmesi. Selçuk Üniversitesi Illetişim Fakültesi Akademik Dergisi, 11(2), 232-251.

Ott, B. L. (2017). The age of Twitter: Donald J. Trump and the politics of debasement. Critical studies in media communication, 34(1), 59-68. 
Pariser, E. (2011). The filter bubble: What the Internet is hiding from you. UK: Penguin.

Persily, N. (2017). The 2016 US election: Can Democracy Survive The Internet?. Journal of democracy, 28(2), 63-76.

Resnick, P., Garrett, R. K., Kriplean, T., Munson, S. A., Stroud, N. J. (2013, February). Bursting Your (filter) Bubble: Strategies for Promoting Diverse Exposure. In Proceedings of the 2013 ACM Conference on Computer Supported Cooperative Work Companion(pp. 95-100).

Sismondo, S. (2017). Post-truth?, Social Studies of Science, Vol. 47(1) 3-6, https://journals. sagepub.com/doi/pdf/10.1177/0306312717692076

Swire, B., Berinsky, A. J., Lewandowsky, S., Ecker, U. K. (2017). Processing Political Misinformation: Comprehending the Trump Phenomenon. Royal Society Open Science, 4(3), 160802 .

Taş, O. ve Taş, T. (2018). Post-Hakikat Çağında Sosyal Medyada Yalan Haber ve Suriyeli Mülteciler Sorunu. İleti-ş-im 29, ss. 183-207, http://iletisimdergisi.gsu.edu.tr/tr/download/articlefile/605971, Erişim tarihi: 15.02.2020.

The European Commission (2018). A multi-dimensional approach to disinformation Report of the independent High level Group on fake news and online disinformation. file:///Users/fulyasen/ Downloads/KK0118221ENN.en.pdf, Erişim tarihi: 14.08.2019.

Van Dijk, T. A. (2000). Ideology and discourse: A Multidisciplinary Introduction. http://www. discourses.org/OldBooks/Teun\%20A\%20van\%20Dijk\%20\%20ldeology\%20and\%20Discourse. pdf, Erişim tarihi: 10.09.2019.

Wikforss, C. (2020). Deliberative democracy could be used to combat fake news - but only if it operates offline, https://www.democraticaudit.com/2020/02/06/deliberative-democracycould-be-used-to-combat-fake-news-but-only-if-it-operates-offline/, (06.02.2020), Erişim tarihi: 14.02.2020.

Woolley, S. C., Guilbeault, D. R. (2017). Computational Propaganda in The United States of America: Manufacturing Consensus Online. Computational Propaganda Research Project, 22.

\section{İnternet Kaynakları}

OED (2016). "Word of the Year 2016 is...", 10 Eylül 2019 tarihinde https://languages.oup.com/ word-of-the-year/word-of-the-year-2016 adresinden edinilmiştir.

Sahte Haber Karnesi (2019). 18 Haziran 2019 tarihinde https://teyit.org/wp-content/ uploads/2019/05/Rapor-YS-2019-1.pdf adresinden edinilmiştir.

The post-truth world: Yes, l'd lie to you (2016). 15 Eylül 2019 tarihinde https://www.economist. com/briefing/2016/09/10/yes-id-lie-to-you adresinden edinilmiştir.

2019 yerel seçimlerinde internette yayılan 42 yanlış bilgi (2019). 30 Haziran 2019 tarihinde https://teyit.org/2019-yerel-secimlerinde-internette-yayilan-yanlis bilgiler/ adresinden edinilmiştir. 